\title{
HUMANISM IN ISLAMIC EDUCATION: INDONESIAN REFERENCES
}

\author{
Abur Hamdi Usman* \\ International Islamic University College Selangor, 43000 \\ Kajang, Selangor, Malaysia \\ E-mail: aburhamdi@kuis.edu.my \\ Syarul Azman Shaharuddin ${ }^{* *}$ \\ International Islamic University College Selangor, 43000 \\ Kajang, Selangor, Malaysia \\ E-mail: syarulazman@kuis.edu.my \\ Salman Zainal Abidin ${ }^{* * *}$ \\ International Islamic University College Selangor, 43000 \\ Kajang, Selangor, Malaysia \\ E-mail: salman@kuis.edu.my
}

Published online: 15 January 2017

To cite this article: Usman, A. H., Shaharuddin, S. A. and Zainal Abidin, S. 2017. Humanism in Islamic education: Indonesian references. International Journal of Asia Pacific Studies 13 (1): 95-113, http://dx.doi.org/10.21315/ijaps2017.13.1.5

To link to this article: http://dx.doi.org/10.21315/ijaps2017.13.1.5

\begin{abstract}
In the context of nationality, the role of education is to prepare students to face the future and promote a sense of dignity among other nations. For Indonesia, humanistic values were incorporated and formulated into Pancasila, which is often referred to as humanistic-universalistic. This paper aims to review the formulation of national education goals that are in sync with the concept of universal humanistic education. It investigates an Islamic education as an integral part of Indonesian national education can achieve both national and humanistic education goals without contradicting each other or the teachings of Islam. The finding implies that orientation of the education system in Islamic educational institutions starts with a theocentric philosophy, which emphasises the importance of the afterlife over life in this world. Throughout the educational process, students intensively explore the comprehensive teachings and practices of Islam. Islamic teachings explicitly describe the practice of Islam in terms of the
\end{abstract}


implementation of Islamic humanism. Therefore, an emphasis on moral goodness, unity and brotherhood and the cultivation of independence in Muslim characters are the main pillars of Islamic humanism in the Islamic educational institutions. As a concept, this paper suggests that the implementation of Islamic humanism would require a policy that is conducive to the realisation that the concept must be humane and must become a reality. Responsibility for such a policy would be shared among all components of the nation, from the government, as the main educational policymaker, to the schools that provide education and the parents and the community that will benefit from the education. These factors are responsible for the realisation of humanistic education.

Keywords: Humanism, Islamic education, Indonesia, Pancasila, theocentric philosophy

\section{HUMANISM: HISTORICAL PERSPECTIVES}

The term "humanism" has a complex history and meaning. "Humanism" as a term came to prominence in philosophical discourse in the early 19th century. It was initially used in German literature in approximately 1806 and in England in approximately 1860. Previously, the concepts of humanism or humanistic had long been known as humanum (human) (Douzinas 2003; Meserve 1982), a concept that began near the end of the scholastic era in Italy in the 14th century and spread to almost all of Europe in the 16th century. As a humanist concept, humanum was intended to break the barriers of the church that repressed freedom, creativity, and human reasoning; it was inspired by the florescence of Roman and Greek culture. The humanist movement evolved and became the forerunner of the Renaissance era in Europe (Bertens 1987).

In the early blooming of humanism in Europe, humanism received persistent opposition from religion (in this case, Christianity). This opposition reached its peak when Auguste Comte (1798-1857) declared a "humanitarian religion" to be a replacement for religion, which was considered inhumane (Blanchard 1918; Bevir 2002). This conflict continued until the mid-20th century, when the Christian leaders began to show an appreciation for humanism. At the Church Council of Vatican II (19621965), the Catholic Church gave a positive response to humanism. In addition, when religion started to appreciate humanism, philosophy propagated an anti-humanism discourse, especially with the works the Death of Man by French social theorist Michel Foucault (1926-1984) and Human Absurdity by Albert Camus (1913-1960), a Nobel Prize-winning 
French philosopher. His views contributed to the rise of the philosophy known as absurdism.

From a historical perspective, humanism was derived from an intellectual and literary movement and became a driving force of modern culture, particularly in Europe. Furthermore, from a philosophical view, the humanistic ideology or concept upheld the value and dignity of human beings; accordingly, man occupies a very important and central position in both theoretical-philosophical reflection and practical life (Gundara 2000). Next, this philosophy says that everything is based on the size of the assessment and that the final reference point for all human events is the human itself and not forces beyond humanity (e.g., God or nature). Humanism as an intellectual and literary movement in principle was a fundamental aspect of the Renaissance (14th-16th century AD). The goal of the humanism movement was to break away from the Church's power and free the mind from the shackles that bind (Gelder 2012; Perry 2012). Therefore, with certain limitations, any form of outside force that restricts human freedom must be broken. Freedom was the most important theme of humanism; however, it was not meant to promote absolute freedom but freedom that was the antithesis of the medieval determinism adopted by people of the Church at the time. However, this does not mean that humanism at that time was against the existence of God's power. Humanists believed that behind the power of God, there were many opportunities to determine their way of life, to improve their potential and to make their own future without any restrictions from nature or fear of the wrath of God. They believed that human freedom existed and needed to be maintained and expressed. As explained previously, humans are the centre of reality, and everything that is part of reality must be returned to humans. Therefore, an assessment or interpretation of an event or phenomenon that makes humans themselves marginal or rim entities (peripheral) is not justified (Iovino 2010).

If humanism is defined in this way then certain philosophies, such as Marxism, pragmatism, and existentialism, can be categorised into humanism (Hammersley 2004):

- $\quad$ The school of Marxism essentially places a human state (community/workers) at the centre of life. Theoretically, it at least upholds the dignity and humanity of the labour community.

- $\quad$ Pragmatism is also humanism because it also places humans at a central position within reality. Everything that exists is 
always associated with its usefulness for providing humans with a better life.

- Existentialism is also included in humanism. According to this ideology, there is no world beyond the human world, and within that world, humans have the most central position.

Humanism has developed to no longer refer to the liberation movements that took place during Renaissance or to doctrines that imprison men, and it now thrives in the sciences (Reid 2001). For example, we often hear about humanistic science, but what does that mean? Dilthey Wilhelm's (18331911) idea of Geisteswissenchaften provides an early guideline to answer the questions above. The term Geisteswissenchaften can be translated as "sciences of man." According to Dilthey (1989), the scientific disciplines are what we usually call the social sciences, such as economics, psychology, cultural anthropology, sociology, law, and political science.

\section{WHAT IS HUMANISM?}

The historical facts tell us that humanism was an outcome of traditional western culture and not of eastern culture (Xiaoming 2001). The term "humanism" was an invention of the 19th century. In German, it is known as Humanismus, a term that was first used in 1808 to refer to a form of education that provides the main place for the mastery of classical Greek and Latin. In English, "humanism" began to appear somewhat later. The first recorded appearance of the term comes from the writings of English poet, literary critic and philosopher Samuel Taylor Coleridge (1772-1834), who used the word "humanism" to indicate a Christological position, namely, the belief that Jesus Christ was purely human. The word was first used in the context of culture in 1832 (Davies 2008).

In terms of language, "humanism" is derived from the Latin word humanus and has a root word meaning homosexual men. Humanus means "in accordance with human nature" (Giustiniani 1985). Originally, humanism was a movement that emphasised dignity and human values. As part of the flow of critical thinking that comes from the movement that upholds humans, humanism emphasises the dignity, role and responsibility of humanity. Humanism itself has always been attributed to philosophical outlook that places humans in a particular position and makes it the size of everything. In terms of history, humanism originally referred to literature, culture, thought, and education; however, as it developed, it started to show its political nuances. In other words, either consciously or unconsciously, 
humanism spread to all aspects of society in the forms of communism, utilitarianism, spiritualism, individualism, existentialism, liberalism, and the Protestantism of Martin Luther (1483-1546), a German friar, priest, professor of theology, and a seminal figure in the Protestant Reformation. Furthermore, since the seventeenth century, what was called humanism has been obliged to lean on certain conceptions of man borrowed from religion, science, or politics. Humanism serves to colour and to justify the conceptions of man in which it must take recourse (Monatschrift 1984).

\section{HUMANISM IN ISLAMIC EDUCATION: METHODS AND IMPLICATIONS}

Humanism is not an ideology that stops within itself. It has ideas about humanity's far-reaching impact on other domains, particularly education. An understanding of human values will greatly affect the implementation of education. Next, to create the ideal paradigm for education, the study of humans is necessary to humanism and to how its concepts apply to education. The implications of humanism for education initially addressed human nature itself in education, namely, that humans are multidimensional beings that have the potential for religious consciousness. In the end, humanity is the vessel of the investigation that leads to the ideological liberation of society through enlightened humanistic education (Veugelers 2011).

However, humanistic education has different philosophical foundations. According to Aloni (2002), humanistic education distinguishes itself in terms of the cultural-classical, the naturalistic-romantic, the existential and the critical-radical approach. From the cultural-classical tradition, we can learn that developing rationality, autonomy and knowledge about human traditions can strengthen a person's agency and allow them to develop an efficacy for learning about the world as a whole and about the tensions between personal autonomy development and social change (Veugelers 2007). According to a humanist point of view, social change is not possible without strong, critical, autonomous people. Without a foundation in social change, autonomy development only glorifies the individual, not humanity. Autonomy and social concern should be considered interlinked; that is, autonomy development should be embedded in social change processes (Freire 1985). Therefore, education means that the goal of learning is not a technical-instrumental rationality but is the development of identity in a reflective and dialogical way within a social context; it is morally a form of social constructivism (Veugelers 2011). 
Humanism as the foundation of education (Finger 1995) is in line with the notion of Islamic education because of all its efforts aim to develop human nature and potential humanism (Arabic: Insaniyah) towards the formation of the perfect man (insan kamil) and in accordance with the norms of Islam. Islamic education can be definitively interpreted as any attempt to develop human nature and potential insaniyah towards the formation of the insan kamil in accordance with the norms of Islam. The whole concept of "human" in general can be understood to refer to a human person who has faith and fear and manifests piety both vertically (in his or her relationship with Allah) and horizontally (in his or her relationship with man and nature).

The process of Islamic education began with understanding the basis of the creation of man because man is the main subject of the educational process. From this awareness, the ideals of an Islamic-minded humanist education can be formulated. The relevance of humanism to education is not a new topic of discourse. Basically, there are two different entities: if humanism is at the philosophical level, then education is the praxis. In addition, education is considered an effort to implement the idea of humanism. The education processes that directly touch people enable us to implement the idea of humanism. A traditional notion of humanism as an educational foundation was practiced for centuries in Ancient Greece. However, it developed into a firm curriculum during the Middle Ages. A liberal arts curriculum was an ideal proposition at that time. That curriculum not only addressed aspects of the mind but also the feeling and will. This approach was closely related to an understanding of the nature of humans as beings composed of various aspects.

Islamic education based on humanism will depart from the affirmation of human sovereignty and instead view the individual as a subject who has the self-awareness to arrange the objects in his or her environment and act solely for the benefit of mankind. As willed creatures, human beings are free and autonomous in attitude. However, a free will also needs to be balanced with responsibility. The suppression of human subjectivity can have an impact on the dominating and exploitative nature of humanity, which could otherwise lead to ecological crises that affect the balance of nature. In this way, education is designed not solely to serve the issue of human sovereignty but to formulate values.

Humane education based on this transformative paradigm departs from the basic tasks of human undertaking in the world. Education is nothing but an attempt to succeed in a task. Muhaimin (2002) cites Mustafa Al-Maraghi (1881-1945), an Egyptian reformer and rector of Al-Azhar, who suggested a form of human mandate, as follows: 
- A mandate toward the Lord in the form of an obligation to follow His commands and avoid His prohibitions and use all the potential and ability to perform activities that could be useful for drawing closer to Him.

- $\quad$ A mandate toward fellow human beings; namely, to fulfil the individual rights of others, to not commit fraud and to be wise without indulging in other people's secrets.

- A mandate of man towards himself to try do things better and in a way that is more beneficial to himself for the sake of religion and the world and not to do things that endanger the life around him and his religion. The consequence is that education does not merely stop at forming an individual's identity but further aims to develop the individual's vision of the common good shared with other individuals. This enables education to transform society for the progress of civilisation.

What must be noted here is that Humanism refers to an atheistic humanism rather than to humanism in the sense of an ethical and broadly applicable approach. Atheistic humanism has the view that:

1. Everything, including religion, is assumed to originate from nature, without God's involvement in it. Religion is the result of purely human creativity itself.

2. Humans have the potential to determine which behaviours and values are considered the best and to value the primacy of human emotion independent of the values of restraint, especially sacred values that were believed to come from God. Thoughts place this type freedom in its historical context, and religious dogmatists deny a role in determining the value of human life as a regulator of human behaviour. God can only be understood as a partial conviction that can grant freedom without being able to determine how a person can act.

\section{THE PRACTICAL IMPLEMENTATION OF HUMANISM IN THE ISLAMIC EDUCATIONAL SYSTEM}

Islamic education and learning activities have branched out to include media and activities to build awareness, maturity and selfhood. Awareness, maturity and selfhood are becoming the purpose of education in Islam; 
education, as a process of social interaction that involves the influence of educators and learners to achieve a desired behaviour, is the core of the mission of the code of Islamiyah (Islam). Social interaction in the education system plays an important role in determining the value of nationality. That is to say, students who have a sense of social solidarity will form a society that is aware of the importance of unity within the social system. When this awareness arises within each learner, they will form a nation that upholds a spirit of national unity and avoids restlessness, which contradicts the spirit of humanism.

Teachers who transmit knowledge, even to non-Muslims, are serving Islam because they benefit humanity (Mohamed 2007). Islamic education as the development of appropriate guidance towards the meaning of tarbiyah (education) defines the teacher as a facilitator who gives directions for potential learners to process. A teacher becomes the students' learning partner to help them actualise their potential. Therefore, the purpose of Islamic education is to prepare the individual to reach all the potential that exists in both body and spirit to achieve the perfection of a useful human life. Stated in another manner, Islamic education aims to initiate total change in a person's beliefs, actions, energies, potential, faculties, aspirations, thoughts, expressions, and everything related to being human; these factors contribute to the balanced development of the whole personality of a human being as the vice-regent of Allah on Earth.

This approach should focus on the transfer of moral values in education. Moral values are abstract and normative because they say something about the good life, about good and bad. However, in this view, morality consists of virtues and traits that support good behaviour. Being a good moral example and teaching students about good moral people are important teaching methods in this approach (Sockett 1993).

The education system should develop an ability to detect when moral values are involved and how meaning is attributed to them. This implies noticing how students position themselves, give meaning to their experiences and the world around them, and work with the values are involved in these processes. This approach can be situated within a national educational system that is concerned about its cultural heritage or within a tradition that is based on a religious worldview that perceives itself as more static than dynamic (Veugelers 2010).

Therefore, in the attempt to become more humanised, Islamic education is operationally provided for two purposes:

1. To emancipate the learner from all forms of dogmatic systems that cripple natural human creativity. "Dogmatism" here is 
not synonymous with a particular religious belief or doctrine. In the Greek tradition, dogmatism is referred as a myth or a statement that is baseless but is fanatically and exclusively maintained as truth.

2. To encourage the process of self-transformation from apathy and fatalism towards critical consciousness. Critical awareness lets people realise what is happening in their environment and what must be done about it.

Therefore, people can develop their social awareness and individuality in balance at the same time. The duality of human existence is a major dimension of human beings and should be developed through education. A person's capacity as both an autonomous individual and a member of society is the basis of Islamic education in practice. The implementation of humanism in Islamic education is an urgent need, given the vital role of education in individual and community cultural development. In the context of formal education, education is divided into various aspects of paradigmatic change, namely the teacher aspect, the method aspect, the student aspect, material aspects, and evaluation aspects. Afsaruddin (2005) notes the thoughts of Muhammed Fethullah Gulen, who emphasised a humanistic approach not just to the sciences but to education overall, which reflects an earlier pattern of classical education in the Islamic world. According to Gulen (b. 1941), such a broad-based humanistic approach would include the inculcation of religious, ethical and traditional cultural values, which in their application are universal and broadly humanitarian. Humans should also not be severed from the history of their community, whether as individuals or as nations, because a highly developed historical consciousness provides a valuable contextualised perspective of contemporary life.

\section{HUMANISTIC VALUES IN THE PHILOSOPHY OF EDUCATION IN INDONESIA}

There is a close relationship between humanism, education and citizenship. As a system of rules, citizenship encompasses national cultural norms, which are important for people involved in developing their countries. Dewey (1923) stated that citizenship is concerned with a person's standing society, the personal meanings of life, and the interpersonal and sociopolitical levels of the countries. 
In the 1920s, Indonesian educator Ki Hajar Dewantara launched the idea that education is basically humanising humans. To achieve this aim, education must be based on the principle of family relationships, kind heartedness, empathy, love, and respect for every member. To this end, Indonesia with its multiculturalism should adopt a method of education based on Ing ngarso sung tulodho, Ing madyo mangun karso, Tut wuri handayani (Dantes 2012). In relation to this, the Education Ministry of Indonesia has made character development one of the goals of Indonesian education. Character education can be developed through social interactions based on virtue, which consists of values, morals, and norms (Wardono et al. 2015). Therefore, the humanist philosophy of the education system in Indonesia is based on Pancasila (namely, the values of divinity, humanity, nationality, democracy and justice), which already involves humanistic values (Rahman 2011). These values were used as the basis for formulating the national education system policies. According to Rahman (2011), these values can be expressed as characteristics of an education system based on the humanitarian values of Pancasila, which are discussed in detail below.

\section{Respect the Religious Beliefs of Each Person}

As the first principle of Pancasila states, belief in the Almighty indicates that the Indonesian people must be theocentric, which in Islam was defined as Tauhid. Theocentrism in humanistic education develops the potential of a child to become a human being. This orientation, according to Barnadib (1988), aims to prevent people from becoming mono-dimensional. This effort requires awareness that the development potential of learners should not be separated from the spiritual power of religion.

This religious orientation should be integrated with efforts to form a human being who has faith and a fear of God and does not lose his or her national characteristics. This can be achieved by a national education system that is rooted in religious values and national culture. Fullan (2001) said, "Changes in beliefs are even more difficult; they challenge the core values held by individuals regarding the purposes of education." Religious beliefs play a strong role in determining the orientation of a nation's educational system. Husain and Ashraf (1978), in their book, Crisis of Islamic Education, consider that Islamic education places great emphasis on the realisation that fostering faith and piety in a person is the fundamental purpose of both the special features of Islamic education. The urge to study the teachings of Islam can be used to reinforce this awareness.

Education, as part of the human effort to work towards a glorious future, is a self-improvement process for each individual. This indicates the 
need for self-discipline, which can only be achieved through education as a process of acculturation. Education that is solely a pattern of knowledge transfer and not a civilising process is essentially indoctrination. Against this action, Rahman (1982), in Islam and Modernity, stated: "As for indoctrination in the sense of brainwashing, I have already noted that this technique of creating future generations of the faithful in fact ultimately backfires."

Indoctrination in education can suppress generations, which in turn can lead to rebelliousness. This method of education was accurately judged to be unsuccessful in carrying out its duties. The development of Islamic education in Indonesia needs to be based on social reconstruction and move towards an anthropomorphism that departs from theocentrism. Humanising efforts in an Islamic education system in Indonesia should be based on the values of Pancasila and the teachings of Islam. Starting from this idea, the barriers against implementing humanism in Indonesia arise when education leans toward atheism (Siner 2012) or a humanism that forgets the cultural traditions of the nation and the people (grassroots). Paternalistic and authoritarian educational practices are incompatible with the principle of maintaining the creative independence and autonomy of children. Finally, these issues have a serious impact on society.

\section{Respect for Human Dignity and Fundamental Rights}

The principle of just and civilised humanity requires a learning process that emphasises the development potential of learners. Conceptualised learning means that students actively study on their own. The conceptualised learning model has been adopted to ensure the rights of learners because human beings evolved with abilities to match their potential. Studentsboth individually and collectively — need to be understood so that the educational process can succeed. The concept of education must be based on basic assumptions about human beings, especially on their potential or nature. Humanistic education emphasises not just the result of the learning process but tends to create a mechanistic learning process that turns off the mental and creative processes of children.

The education process should be based on respect for the rights, interests and willingness of each learner. Students should also be taught to honour their teachers. In classical Islamic education, honouring the teacher is a necessity (requirement) for students. The negative side of this need to respect the teacher is the emergence of taqlid (following opinions without criticism) and a cult-like attitude towards teachers, although Islam forbids Muslims from being blind towards taqlid. Furthermore, Islam teaches 
Muslims to think rationally and prohibits them following opinions that are not essentially at its core. Many verses in the Quran rhetorically tell the people to think.

Although respect toward the teacher should be a condition of learning, as al-Zarnuji (n.d.) states, it is not intended to kill the creativity of learners. Comity should not lead to cultism because only God is to be worshiped by humans. The requirement to respect teachers exists simply to educate students and develop an attitude of respect (Lickona 1991). Paying tribute to teachers, who serve as a substitute for parents in education, is expected to encourage respect for older people. This attitude also requires a loving attitude towards younger people.

Hence, the barriers of implementing humanism in Indonesia include instances when educational institutions have failed to respect human rights (Mihr 2009). In this context, "plural religious education" is the approach to religion in public schools that best complies with international human rights standards (Evans 2008). Education must have meaning if it is to contribute to the liberation of humanity, and it should be a process of humanisation rather than one of dehumanisation. In other words, education may serve as a catalyst for attitudes that support human rights (Covell and Howe 2001). Education must not only make humans different from animals but should also be a process of humanisation. The essence of education is to establish and implement human values that apply to family and community life. Those values are alive and thriving and developed in a civilised environment. This orientation is becoming necessary for future life on the global scale. The hope is that education in Indonesia can produce humans who are educated and have developed their potential as noble beings that have the spiritual power of religion. Education must produce a religious person who is creative and noble.

\section{Insightful Nationality}

Insightful nationality, as the sole purpose of the Unity of Indonesia principle, calls on humans to be active participants in education. Otherwise, the process of human empowerment will be stunted when freedom slips away (Dewey 1986). There is a need for freedom so that a person's potential can be fully developed. Learning resources need to be adapted not only to the environment but also to the management and implementation of the educational process to meet learners' demands for freedom and rights. This process is oriented towards empowerment, which must become a part of the culture of society so that environmental conditions foster a productive attitude among learners. The liberation paradigm in education is intended to 
empowers learners, communities and countries to provide greater opportunities for personal development that are free and familiar in terms of conscience and humanity and free from physical and psychological pressure. The essential goodness of human nature, a sense of responsibility and a promise to abide by the values of Islamic teachings can form a pattern of education for students. The result is a generation of people who may differ in terms of position and status but can live in harmony, bound by the same faith.

The objectives of educational institutions should not be set strictly. Nobody has ever become a completely 'educated man'. Humans are always on a journey that never stops. According to this attitude, the teachers' engagement with the curriculum is relative. This does not mean that teachers are not important in the classroom. Teachers are a source of material/ideas and provide facilities to define learning objectives. Teachers must accept the thoughts and feelings of students without personal criticism. Educators must also express themselves openly and honestly accept their feelings. This model is not easy because it requires an attitude of independence and high creativity.

\section{Respect for Freedom in Democracy}

As stated in this fourth principle, a democratic soul is based in wisdom, deliberation and representation. These values arise from awareness and the existence of human free will. A humanitarian principle in Islamic humanism is that human beings are noble, thoughtful, self-aware, self-determining, and yearn towards the ideal and moral. The main objective of education, according to Bayrakli (2004), is to help students find themselves (inner dimension), understand their capabilities and discipline themselves. This objective is to make students conscious so that they can realise themselves as men. People determine their own behaviour. A key to this development is self-awareness, an understanding of the as it is and as the individual would like it to be.

Humanistic values are also indicated by an element of democracy in education. Democracy in education provides the best opportunities equally and fairly, respecting the dignity of human beings and opportunities for cooperation that can be accessed by all parties. A democratic society is a common life in which every citizen, both men and women, have dignity and are free human beings. Human dignity entitles a person to be free to have beliefs and convictions that cannot be changed by force or influence.

Democracy as a pillar of humanistic education implies that all children (citizens) have the right to education (Touraine 1997). A 
democratic education also requires that the learning process be open, equal, non-authoritarian and non-discriminatory (Zulkarnain 2014). On this basis, learners should be given freedom. With freedom, humans can develop their potential. To ensure that the potential can be developed harmoniously and to the greatest possible extent, students must be regarded as individuals (personal) and as members of a community. A person who has achieved his or her full potential is one who is active and has a high social sensitivity at the local, national and global levels and has received a multicultural education.

Freedom cannot be interpreted without limits because the absence of restrictions would interfere with the liberty of others (Thayer-Bacon 2008). This belief is equivalent to the notion of rights and obligations. Freedom without restraint results in the loss of human values. Although humans can grow by themselves, religious experience and education will not be fully developed. Younger generations, who grew up in a liberal-secular society, have developed into animals. Rahman (1982) said, "For, if humans could grow by themselves, highly sophisticated religious and educational systems would not have developed in the first place. And what we are seeing develop in societies whose liberals think they are the first secular liberals in human history is that instead of growing into humans, many of the new generation are in fact growing into animals."

Moreover, the implementation of humanism in Indonesia would be interrupted if people tried to separate science from religion (i.e., to create a secular paradigm) (Haught 1995; Colburn and Henriques 2006). Awareness created by knowledge has no soul and dies, so it cannot arouse emotions. When awareness increases, religious beliefs will ignite all human existence. In this matter, Islamic education is concerned with the realisation that developing faith and piety in the individual is the fundamental purpose of both the special features of Islamic education. Faith and piety that became the basis of wisdom are the soul of the fourth principle of Pancasila. In the process of humanisation and to impact social awareness, education must treat learners wisely so that it does not conflict with the values of humanism.

\section{Uphold and Enforce Social Justice among Learners}

As a form of prudence, social justice is the fifth principle of Pancasila that is necessary in the education process. Social justice reflects the social piety that emerged from the religious consciousness of the nation. The sacred teachings of Islam can be used to strengthen the awareness of faith and piety. That recognition comes not because of pressure, which is contrary to 
the concept of humanism, but because of the freedom that self-learners have to assess the positive and negative aspects of deeds.

Freedom allows humans to be intelligent beings who can choose the good and true. This is the privilege of man according to humanistic education based in Islamic thought. Therefore, the values of Islam that should illuminate Islamic education are not contrary to humanism. Islamic education is a humanistic education based on faith and pious charity that create human life and a society based on justice, peace and prosperity.

Moreover, the Islamic mission is to establish a society that is just, healthy, harmonious and prosperous both materially and spiritually. The process of learning in Islamic education should be rooted in spiritualreligious belief to produce people who are rational-critical-empiricalobjective-mathematical, creative, independent, free, open and professional; who remain committed to the values of trusting other people; who have a consistent attitude towards their fellow human beings and do not treat other beings and nature around in an arbitrary manner; and are able and willing to be accountable before God. Indonesia is a pluralistic nation in terms of religion, race, ethnicity, traditions, culture, and other human qualities and intellectual, professional, moral and spiritual values. All these factors are meant to actualise the rights and obligations of humans that gain God's pleasure.

Based on this pluralism, a humanistic paradigm of Islamic education in Indonesia aims to realise human values based on Pancasila. The principle of the Almighty Deity shows that religion is a source of ethics and morals in the nation of Indonesia. Humanistic education seeks to acknowledge the Indonesian people, who want to live by the values of religion. Religious values are a basis for all activities of human life. The second principle is a just and civilised humanity, which includes the values of democracy and human rights. Humanistic education provides a meaning for life that is shared with other Indonesian people and allows them to work together to achieve desired goals. Indonesia is a human and humane society that recognises human rights. The third principal, the unity of Indonesia, is a tool for the joint life of the Indonesian nation. Humanistic education should develop a diverse community and a culture of human humanists to elevate the image of the nation.

Indonesia's Pancasila is the profile of the Indonesian people. The values outlined in the five principles of Pancasila form a unified whole that cannot be separated; each of the principles is a value that supports the other values. Tilaar (2004) stated that the integrity of the values of Pancasila ensures the whole humanisation process of the Indonesian people. Within the process of humanisation, certain values receive priority, such as the 
value of believing in one Almighty. The values of humanity also require attention so that the bad image of a nation without culture can be eliminated. Violence and inhumanity are not noble values of the Indonesian nation.

Therefore, the humanisation of Islamic education in Indonesia should not let go of the values of Pancasila. Pancasila was formulated by the founders of the Muslim majority countries, who regard these precepts as a translation of the values of Islamic humanism. Islamic education has a role in shaping Indonesian people who are able and willing to contribute in ways that bring happiness to all mankind. Life is the orientation of humanisticIslamic education.

A humanistic orientation in the national education system can also be viewed in terms of its concept and educational purposes. When education is based on a concept and purpose that is not directly aimed at meeting the needs of society and the state, it becomes oriented toward developing human potential in learners for its own merits. Such study attempts to make individual humans into humanity itself. However, this does not mean that fulfilling the needs of society and the state is not important, and this is not the goal of education in Indonesia.

The national education system aims to meet the need of learners beyond themselves and moves beyond an orientation toward self-fulfilment for its own purposes. Developing high levels of creativity could certainly be beneficial to the world outside and to the learner himself. This orientation aims to achieve individuality without selfishness. This is precisely the orientation of humanistic education, and this is humane, according to the concept of humanism. Therefore, the national education system in Indonesia has come to embody the humanistic education model.

\section{CONCLUSION}

The education system in Indonesia is directed towards producing creative, independent and responsible human resources that embody the concepts of Indonesian national education. This formulation has similarities with the concept of a humanistic education system. Islamic education, as a subset of a national education system, attempts to achieve these goals based on Islamic concepts. The role of Islamic education in building human character is to encourage a willingness to spread kindness and charity that will bring happiness to mankind.

The principle that upholds human rights within a humanist vision of Islamic education is meaning, and education should not marginalise learning based on human values. The value system in Islamic humanism also plays a 
role in rectifying the failure of the education system, which is currently stuck in a dehumanisation process. Only learning that considers humanistic values can be considered an education system. This concept is an interpretation of the writings of Muslim scholars because their efforts to develop human values will form the basis of Islamic humanism.

\section{NOTES}

* Abur Hamdi Usman is a PhD holder of Islamic studies from Universiti Kebangsaan Malaysia. He received MPhil and PhD in the Sciences of the Qur'an. He was a student in the University of Al-Azhar, Cairo, Egypt. He has published numerous refereed articles on theology, Quranic exegesis, Hadith sciences and Islamic studies. His areas of interest include Islamic civilisation and Quranic Studies. He travels and lectures widely. Currently, he is a senior lecturer at Selangor International Islamic University College (KUIS) and a Head of Hadith Unit in Selangor Hadith Research Institute (INHAD).

** Syarul Azman Shaharuddin is a senior lecturer at the Faculty of Islamic Civilisation Studies, Selangor International Islamic University College (KUIS), Malaysia. He received his $\mathrm{PhD}$ in Islamic civilisation in Universiti Kebangsaan Malaysia. His research interests include dakwah and its management, education, and Muslim converts in ASEAN. He has written chapters in books and many articles in internationally refereed journals.

*** Salman Zainal Abidin is a lecturer and Director at the Student Development Division of Selangor International Islamic University College (KUIS). His research interests are on Islamic thought, hermeneutics, Islam and post-modernism, education issues, gender and politics in Southern Asia. He has written some articles in internationally refereed journals. His publications include "Wasatiyyah Discourse by the Perspective of Indonesian Muslim Scholars," Mediterranean Journal of Social Sciences, Vol. 6, No. 5 (201).

\section{REFERENCES}

Afsaruddin, A. 2005. The philosophy of Islamic education: Classical views and M. Fethullah Gulen's perspectives. Presented in Conference of Islam in the Contemporary World: The Fethullah Gülen Movement in Thought and Practice, Boniuk Center for the Study and Advancement of Religious Tolerance, Rice University, Houston, 12-13.

Aloni, N. 2002. Enhancing humanity. Dordrecht: Kluwer.

Al-Zarnuji, B. I. n.d. Ta'lim al-Muta'allim: Tariqah al-Ta'allum. Semarang: Toha Putera.

Barnadib, I. 1988. Ke arah perspektif baru pendidikan. Jakarta: Departemen Pendidikan dan Kebudayaan.

Bayrakli, B. 2004. Prinsip dan metode pendidikan Islam: Sebuah paradigma baru pendidikan yang memanusiakan manusia. Jakarta: Inisiasi Press. 
Bertens, K. 1987. Fenomenologi eksistensial. Jakarta: Gramedia.

Bevir, M. 2002. Sidney Webb: Utilitarianism, positivism, and social democracy. The Journal of Modern History 74 (2): 217-252.

Blanchard, P. 1918. A psycho-analytic study of Auguste Comte. The American Journal of Psychology 29: 159-181.

Colburn, A. and Henriques, L. 2006. Clergy views on evolution, creationism, science, and religion. Journal of Research in Science Teaching 43 (4): 419-442.

Covell, K. and Howe, R. B. 2001. Moral education through the 3 Rs: Rights, respect and responsibility. Journal of moral education 30 (1): 29-41.

Dantes, N. 2012. Techno-humanistic-based character education (A series of perspectives and education policies for meeting global challenges). Proceedings of the Asian Conference on Education, Osaka, 1632-1644.

Davies, T. 2008. Humanism. London: Routledge.

Dewey, J. 1923. Democracy and education. New York: Macmillan. . 1986. Experience and education. The Educational Forum 50 (3): 241-252.

Dilthey, W. 1989. Selected works. Princeton, NJ: Princeton University Press.

Douzinas, C. 2003. Humanity, military humanism and the new moral order. Economy and society 32 (2): 159-183.

Evans, C. 2008. Religious education in public schools: An international human rights perspective. Human Rights Law Review 8 (3): 449-473.

Finger, M. 1995. Adult education and society today. International Journal of Lifelong Education 14 (2): 110-119.

Freire, P. 1985. The politics of education. South Hadley, MA: Bergin \& Garvey.

Fullan, M. 2001. The new meaning of educational change. New York: Teachers College Press.

Gelder, H. A. E. 2012. The two reformations in the 16th century: A study of the religious aspects and consequences of renaissance and humanism. New York: Springer.

Giustiniani, V. R. 1985. Homo, humanus, and the meanings of 'humanism.' Journal of the History of Ideas 46 (2): 167-195.

Gundara, J. 2000. Religion, human rights and intercultural education. Intercultural education 11 (2): 127-136.

Hammersley, M. 2004. Action research: A contradiction in terms? Oxford Review of Education 30 (2): 165-181.

Haught, J. F. 1995. Science and religion: From conflict to conversation. New York: Paulist Press.

Husain, S. and Ashraf, S. A. 1978. Crisis in Muslim education. London: Hodder \& Stoughton.

Lickona, T. 1991. Educating for character: How our schools can teach respect and responsibility. New York: Bantam Books.

Iovino, S. 2010. Ecocriticism and a non-anthropocentric Humanism. Local Natures, Global Responsibilities: Ecocritical Perspectives on the New English Literatures 15: 29-53.

Meserve, H. C. 1982. Nobody here but us humanists. Journal of religion and health, 21 (3), pp. 179-183.

Mihr, A. 2009. Global human rights awareness, education and democratization. Journal of Human Rights 8 (2): 177-189. 
Mohamed, Y. 2007. The educational theory of Fethullah Gülen and its practice in South Africa. In Conference Proceedings: Muslim World in Transition: Contributions of the Gülen Movement, 552-571.

Monatschrift, B. 1984. What is enlightenment? In The Foucault reader, ed. Rabinow, P., 32-50. New York: Pantheon Books.

Muhaimin. 2002. Paradigma pendidikan Islam: Upaya mengefektifkan pendidikan agama Islam di sekolah. Bandung: PT. Remaja Rosdakarya.

Perry, M. 2012. Sources of the Western tradition, vol. II: From the Renaissance to the present. New York: Cengage Learning.

Rahman, F. 1982. Islam and modernity: Transformation of an intellectual tradition. Chicago-London: The University of Chicago Press.

Rahman, M. 2011. Pemikiran pendidikan humanistik dalam Islam. Jurnal Kajian Islam 3 (2): 1616-178.

Reid, J. 2001. Dilthey's epistemology of the Geisteswissenschaften: Between Lebensphilosophie and Wissenschaftstheorie. Journal of the History of Philosophy 39 (3): 407-436.

Siner, S. 2012. A theory of atheist student identity development. Journal of the Indiana University Student Personnel Association 2 (7): 14-22.

Sockett, H. 1993. The moral base of base for teacher professionalism. New York: Teachers College Press.

Thayer-Bacon, B. 2008. Beyond liberal democracy in schools. New York: Teachers College Press.

Tilaar, H. A. 2004. Paradigma baru pendidikan nasional. Jakarta: Rineka Cipta.

Touraine, A. 1997. What is democracy? Boulder: Westview Press.

Veugelers, W. 2007. Creating critical-democratic citizenship education: Empowering humanity and democracy in Dutch education. Compare 37 (1): 105-119. . 2010. Teaching religions and world views in a plural society: Teachers inbetween society and students. Moral courage and the normative professionalism of teachers, ed., Klaassen, C. and Maslovaty, N., 103-116. Rotterdam: Sense Publishers. . 2011. Education and humanism: Linking autonomy and humanity. New York: Springer Science and Business Media.

Wardono et al. 2015. The realistic scientific humanist learning with character education to improve mathematics literacy based on Pisa. International Journal of Education and Research 3 (1): 349-362.

Xiaoming, H. U. 2001. Oriental physical education and sport need humanism. Sports \& Science, 1: 003.

Zulkarnain, I. 2014. Pendidikan Indonesia: Dari hegemoni dan kuasa pengetahuan ke pendangkalan kemanusiaan. Sosiologi 1 (1): 56-63. 